\title{
IMPACT OF LOW NUTRIENT INTAKE ON INFANT MORTALITY RATE IN SUB-SAHARAN AFRICA
}

\author{
Ijaiya GT*¹ and AA Yahaya ${ }^{2}$
}

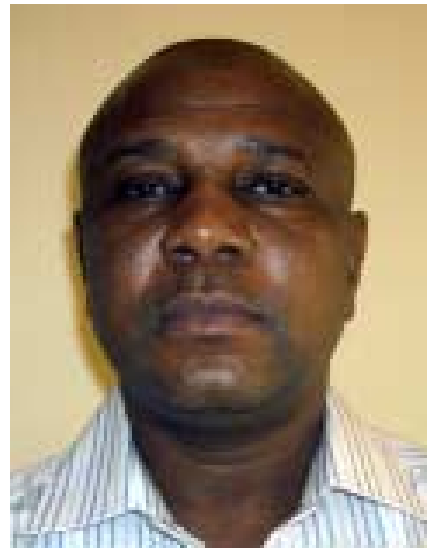

\section{Gafar Ijaiya}

*Corresponding author email: gtijaiya@yahoo.com

${ }^{1}$ Gafar T. Ijaiya is a poverty analyst and a lecturer in the Department of Economics, University of Ilorin, Ilorin, Nigeria.

${ }^{2}$ Abdulrazaq A. Yahaya is a food security analyst and a lecturer in the Department of Liberal Studies, Kwara State Polytechnic, Ilorin, Nigeria. 


\section{ABSTRACT}

Eating good quality food is necessary for good health given the importance of food to the people as one of their most basic needs, which they cannot live without, because it gives energy for everything they do (walking, working, talking, playing, reading and even thinking and breathing). Food also provides the energy for the nerves, muscles, heats and glands to work; and the nourishing substances the bodies require to build and repair tissues and regulate the body organs and systems.

Given these assertions, a healthy body through adequate nutrient intake will not only affect the capacity of an individual to learn, but will improve the well-being and the productivity of that individual and the economic growth of the nation in general. Adequate nutrient intake will not only reduce the tendency for individuals to contact communicable diseases like tuberculosis, but if not properly managed can increase diseases of dietary excess like obesity. On the contrary, when there are inadequate intakes of nutrients, the resultant effect will include malnutrition, which in turn could lead to impaired mental development, poor scholastic and intellectual performance and a wide range of illnesses, disability and possibly death, most especially among infants.

Using a cross-country data, drawn from sub-Saharan Africa and a multiple regression analysis, this paper examines the extent to which low nutrient intake has impacted on infant mortality rate in sub-Saharan Africa. The results obtained first indicate that the model used for the study is of good fit, since 61 percent variation in the dependent variable (infant mortality rate) is explained by the independent variables (low nutrient intake, proxied by daily per capita calories intake and per capita income). Second, the result also indicates that low nutrient intake has a significant influence on infant mortality rate and third nutrient intake (drawn from the values of the co-efficient and $\mathrm{t}$-value) has the expected sign, which is inversely related to infant mortality rate, thus fulfilling our a-priori expectation which said that the lower the nutrient intake, the more the rate of infant mortality rate in sub-Saharan Africa.

Given these result, measures such as, increase in food availability, macro-economic stability (especially, a reduction in inflation rate and exchange rate stability), improved nutrition through micro-nutrients fortification and supplementation, ensuring good governance and combating ethnic/religious/ civil conflicts and HIV/AIDS are suggested as possible solutions to improving nutrient intake in subSaharan Africa.

Key words: Food, nutrient, infant, mortality, Africa

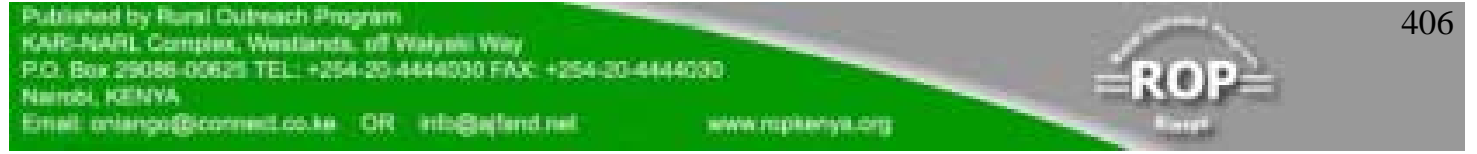




\section{INTRODUCTION}

Several studies on nutrition in developing countries have shown that adequate nutrient intake (daily calories, daily protein, daily fat, minerals and vitamins) is an essential ingredient for improved well-being, economic growth and development, since a healthy body through adequate nutrient intake affects the capacity to learn which in turn determines productivity and economic growth. Evidence on this from developing countries shows that adult productivity depends to a considerable extent on the contribution of health and nutrition during early childhood $[1,2,3,4,5,6,7,8,9,10]$.

It is also observed that better nutrient intake reduces communicable diseases but can also increase diseases of dietary excess. As diets change, usually to include a smaller proportion of complex carbohydrate, and more sugar and animal fat, people become more susceptible to cardiovascular diseases and to cancers of the colon, prostate and breast. Obesity becomes more prevalent and increases the risk of premature death, particularly from cardiovascular diseases and diabetes. Increased sugar consumption contributes to dental caries and may raise the risk of diabetes. High salt intake increases hypertension, raising the risks of stroke and cardiovascular disease. In children, obesity affects their health by increasing the risk of hyperlipidemia, hypertension and abnormal glucose tolerance. In countries like United States, obese children frequently are targets of systematic discrimination and by adolescence many of them suffer from low self-esteem $[1,11,12]$.

With respect to infants, it is observed that, where good nutrient are available, there will be a healthy condition, which invariably will augment the cognitive brain development of a child and reduce childhood mortality, since the child would be free from physical and mental capacity retardation, delayed motor development, stunting, neuromuscular, speech and hearing disorders, loss of vision and infectious diseases like (measles and diarrhea), respiratory diseases (like tuberculosis), and malaria $[1,13,14,16]$.

On the contrary, the inadequacy of nutrient would cause malnutrition, which in turn could lead to a wide range of illnesses, impaired mental development, low birth weight, poor scholastic and intellectual performance, disability and high rate of mortality rate, most especially among infants $[1,7,13,15,17,18,19,20,21,22,23,24,25,26]$.

Using the United State of America's National Academy of Science's Food and Nutrition Board minimum food, energy and protein requirements of $3000 \mathrm{kcal}$ and 59 grams respectively, some countries in sub-Saharan Africa cannot be said to have benefited from improved nutrient intake, more so when their calculated daily calories and daily protein intakes are linked to other social indicators like infant mortality rate and infant low birth weight $[27,28]$. As indicated in Table 1, none of the sub-regions in sub-Saharan Africa (Central Africa, East Africa, Southern Africa and West Africa) have a daily calorie and protein intakes that is above the benchmarks of $3000 \mathrm{k} /$ calorie for calorie intakes and 59 grams for protein intake. The consequences of these are also

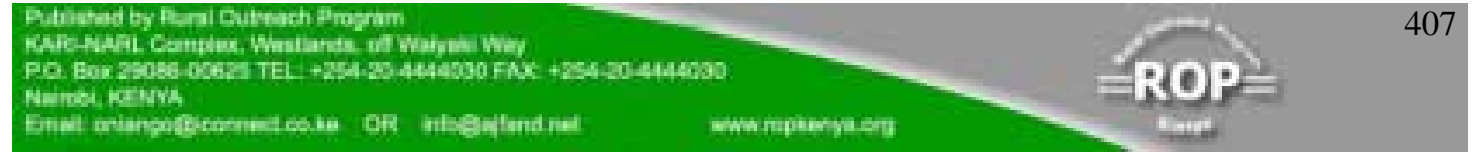


reflected on the infant mortality rates and low birth weight that are high when compared with those of North Africa [28].

Drawing from the above scenario, the thrust of this paper therefore is to verify the validity of the above situations in sub-Saharan African countries, using a crosscountry data and a multiple regression analysis.

\section{MATERIALS AND METHODS}

\section{Materials}

The variables considered for this study are nutrient intake, infant mortality and per capita income. Nutrients are food that are essential for maintaining normal growth and health and usually comprises of calories, protein, fat, vitamins and minerals. Of all these, only calories intake was used as proxy for nutrient intake in order to avoid the problem of multicollinearity in the course of the analysis. [27]. On the other hand, infant mortality is the total number of infants who die under one year of age per 1000 live births in a given year, while per capita income is the ratio of the country's total population to the total national income [28,29].

In the course of determining the impact of low nutrient intake on infant mortality in sub-Saharan Africa, a cross-country data drawn from 48 countries in sub-Saharan Africa for the year 2005 (see Appendix 1) and a multiple linear regression analysis of the Ordinary Least Square (OLS) were used. The data were obtained from the African Development Bank Gender, Poverty and Environmental Indicators for African Countries for the year 2007 [28].

\section{Regression Model}

The first step in the use of OLS method is the specification of the model. In specifying the model for this study emphasis is placed on whether low nutrient intake has any significant impact on infant mortality rate in sub-Saharan Africa. Having established this link, the model is therefore formulated as:

$\mathrm{IMR}_{\mathrm{i}}=\beta_{0}+\beta_{1} \mathrm{DC}_{\mathrm{i}}+\beta_{2} \mathrm{PCI}_{\mathrm{i}}+\mathrm{Z}_{\mathrm{i}}$

Where:

$\mathrm{IMR}_{\mathrm{i}}=$ infant mortality rate per 1000 live births in each country.

$\mathrm{DC}_{\mathrm{i}}=$ daily per capita calorie intake (grams) used as proxy for low nutrient intake in each country.

$\mathrm{PCI}_{\mathrm{i}}=$ per capita income in each country (US\$).

$\beta_{0}=$ the intercept.

$\beta_{1}, \beta_{2}=$ parameter estimates associated with the influence of the independent variables $\left(\mathrm{DC}_{\mathrm{i}}, \mathrm{PCI}_{\mathrm{i}}\right)$ on the dependent variable $\left(\mathrm{IMR}_{\mathrm{i}}\right)$ in subSaharan Africa.

$\mathrm{Z}=$ error term.

To estimate the model, a multiple linear regression analysis is used in order to reflect the explanatory nature of the variables. To verify the validity of the model, two major evaluation criteria were used: (i) the a-priori expectation criteria which is based on the 
signs and magnitude of the co-efficients of the variables under investigation; and (ii) statistical criteria which is based on statistical theory, which in other words is referred to as the First Order Least Square test consisting of R-square $\left(\mathrm{R}^{2}\right)$, F-statistic and $t$ test. The $\left(R^{2}\right)$ is concerned with the overall explanatory power of the regression analysis, the F-statistic is used to test the overall significance of the regression analysis and the t-test is used to test the significant contribution of the independent variables $[30,31]$.

Drawing from the model, our a-priori expectations or expected pattern of behaviour of the independent variables on the dependent variable in the model are: $\mathrm{DC}_{\mathrm{i}}<0$ and $\mathrm{PCI}_{\mathrm{i}}<0$, indicating that the lower the nutrient intake and per capita income, the more the rate of infant mortality rate in sub-Saharan Africa. It is important to note that since equation (1) is an infant mortality rate equation augmented with nutrient intake and an interaction of nutrient intake and per capita income, our main interest therefore centers on the value of the parameter $\beta_{1}$.

\section{RESULTS}

The results of the multiple regression analysis conducted at 5 percent level of significant are presented in Table 2 .

A look at the model shows that it has an R-square $\left(\mathrm{R}^{2}\right)$ of 0.61 , which in other words, means that 61 percent variation in the dependent variable is explained by the explanatory variables, while the error term take cares of the remaining 39 percent, which are variables in the study that can not be included in the model because of certain qualitative features.

At 5 percent level of significance, the F-statistic shows that the model is useful in determining if the independent variables have any significant influence on the dependent variable, as the computed F-statistic which is 12.6 is greater than the calculated F-statistic valued at 2.84. Holding per capita income constant, the coefficient and the $\mathrm{t}$-value of low nutrient intake has the expected sign, thus fulfilling our a-priori expectation. Statistically, it is significant at 10 percent level of significance.

\section{DISCUSSION}

The analysis in Table 2 shows that low nutrient intake that is proxied by daily per capita calories is inversely related to infant mortality. The negative sign of the variable is therefore an indication that the lower the nutrient intake, the higher is the rate of infant mortality in sub-Saharan Africa. A situation that can be linked to several factors which include the following: food insecurity which has to do with inadequate food supply and unequal distribution of food; inadequate care for women and children which has to do with women's education and women's status relative to men's; discrimination against women and improper health environment that has to do with lack of access to safe water, sanitation facilities and health care services; high rate of

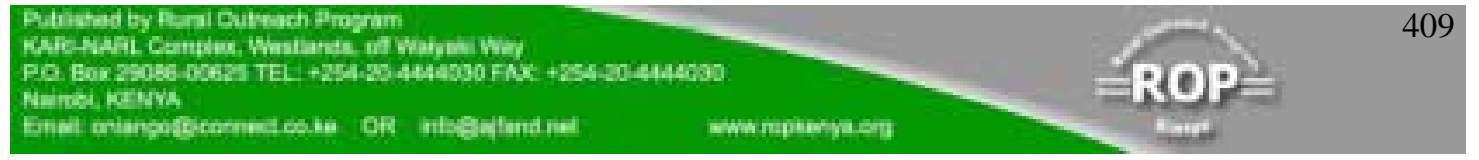


poverty and macroeconomic crisis, which include high inflation rate that has led to increase in the price of food, exchange rate volatility and external debt servicing; socio-political instability (such as, when there are civil conflicts/wars and natural disasters like drought and floods); HIV/AIDS pandemic; lack of democratic values which could have given the people a voice on how government resources can be allocated; and sharp reductions in government expenditure and removal of subsidies in certain agricultural inputs. A careful look at these factors also conforms to views of several authors on nutrition and malnutrition [32,33,34,35,36,37,38].

\section{CONCLUSION AND RECOMMENDATION}

An empirical study of the impact of low nutrient intake on infant mortality rate in subSaharan Africa was carried out, using a cross-country data and a multiple regression analysis. The finding shows that the variable considered as nutrient intakes (daily per capita calorie intake) is inversely related to infant mortality rate, thus fulfilling our apriori expectation. That the variable fulfilled our a-priori expectation is an indication that the lower the nutrient intake the more the rate of infant mortality in sub-Saharan Africa.

To therefore improve the level of nutrient intake in the sub-region, that would reduce infant mortality rate would require among others a situation of macroeconomic stability with strong emphasis on a general reduction in the rate of inflation given its implication on investors and the poor. For the investors, most especially those that are into agriculture and food producing related industries, a reduction in inflation would build their confidence in the economy and cause them wish to invest more in it, while to the people it would help reduce poverty since the poor among them would have enough income to augment their consumption for food and related items.

Other measures should include improvements in food availability through the increase in agricultural production, agricultural research and extension, increase credits to farmers and subsidies on farm inputs and effective market networks. There should be increase in public investment in social services like health care services (to take care of the severity in undernourishment and the infection or dehydration that comes with it), safe water, electricity, good roads and sanitation facilities given their importance to agricultural production, and rounded well-being of the people, most of them farmers.

There is also the need to inform community groups and leaders on the significance of good nutrition for women and children and to also provide nutrition education programmes to women on how to care for their children and themselves with a proper diet and hygiene so as to avoid future nutritional crisis. Sponsoring vaccination, campaigns on nutrition and watching over the growth and development of children should complement the above.

Emphasis should also be placed on micronutrient fortification and food supplementation using iodine, iron/folic acid and vitamin A, given their importance to

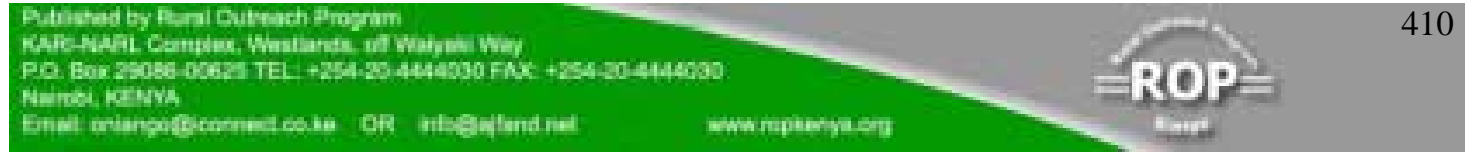


child development. For instance, a child with adequate iron, iodine and vitamin A intakes would be free from anaemia, mental retardation and blindness respectively.

Arresting bad governance and ensuring that democratic principles exist are also essential for improved nutrient intake. Improved governance would be able to tackle the issue of corruption and provide the impetus for accountability, transparency and openness in the provision of incentives that aim at improving the production and distribution of food that would improve nutrient intakes. The existence of democracy would give the people most especially women, a voice on how government resources are allocated, especially to agriculture and social services that are relevant to health.

Combating ethnic/religious/civil conflicts and HIVAIDS that have besieged some countries in the sub-region are also essential. Conflicts as experienced in recent times have been obstacles to collective action on how to arrest hunger since their existence have led to loss of life, destruction of physical, social and human capital, disruption of markets and other forms of economic and social order, diversion of human resources and public expenditure away from the production of food and productivity enhancing activities, migration of people, some of them farmers and transfer of financial assets that would have been used for the production of food to the provision of humanitarian assistance to crisis prone countries. On the other hand, HIV/AIDS has also affected the ability of those living with it, especially farmers to work, to feed themselves and their families, to ward off other diseases, to maintain their assets, to transmit essential farming knowledge to their children and to remain connected to their communities. Eventually, most of them have lost their lives, thus compounding the effort of their country to fight hunger, malnutrition, ill health and even poverty. 


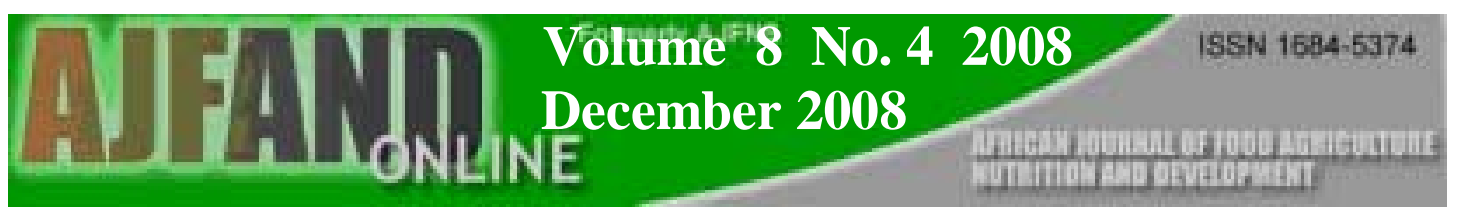

Table 1: Social Indicators and Nutrient Intake in sub-Saharan Africa and North Africa 2005

\begin{tabular}{lcccc}
\hline \multicolumn{1}{c}{ Region } & $\begin{array}{c}\text { Infant mortality per } \\
1000\end{array}$ & $\begin{array}{c}\text { Low infant birth } \\
\text { weight }(\%)\end{array}$ & $\begin{array}{c}\text { Daily per capita } \\
\text { calorie intake } \\
\text { (grams) }\end{array}$ & $\begin{array}{c}\text { Daily per capita } \\
\text { protein intake } \\
\text { (grams) }\end{array}$ \\
\hline Central Africa & 106.1 & 14 & 1821 & 48.1 \\
East Africa & 85.2 & 14 & 2008 & 53.4 \\
Southern Africa & 73.4 & 14 & 2421 & 57.2 \\
West Africa & 107.1 & 16 & 2573 & 61.3 \\
North Africa & 38.2 & 10 & 3052 & 85.0 \\
\hline
\end{tabular}

Source [28].

Table 2: Regression Results of Low Nutrient Intake and Infant Mortality Rate in sub-Saharan Africa

\begin{tabular}{ll}
\multicolumn{1}{c}{ Explanatory variables } & \multicolumn{1}{c}{ Co-efficient or parameter estimates and t-values } \\
\hline Intercept $(\mathrm{t})$ & $119.3(4.57)$ \\
$\mathrm{DC}_{\mathrm{i}}(\mathrm{t})$ & $-0.12(-1.76)^{* *}$ \\
$\mathrm{PIC}_{\mathrm{i}}(\mathrm{t})$ & $-0.93(-4.01)^{*}$ \\
$\mathrm{R}^{2}$ & 0.61 \\
$\mathrm{~F}$ & 12.6 \\
\hline $\mathrm{t}$-values in parenthesis. & \\
$*$ Statistically significant at 5 percent level of significance. ** Statistically significant at 10 percent level of \\
significance.
\end{tabular}

Appendix 1: The Number of Countries Selected for the Study in sub-Saharan Africa

\begin{tabular}{llllll}
\hline Angola & Benin & Botswana & Burkina Faso & Burundi & Cameroon \\
Cape Verde & Central African Republic & Chad & Comoros & Congo & Democratic Republic of Congo \\
Cote D'ivoire & Djibouti & Equat. Guinea & Eritrea & Ethiopia & Gabon \\
Gambia & Ghana & Guinea & Guinea Bissau & Kenya & Lesotho \\
Liberia & Madagascar & Malawi & Mali & Mauritania & Mauritius \\
Mozambique & Namibia & Niger & Nigeria & Rwanda & Sao Tome \& Principe \\
Senegal & Seychelles & Sierra Leone & Somalia & South Africa & Sudan \\
Swaziland & Tanzania & Togo & Uganda & Zambia & Zimbabwe \\
\hline
\end{tabular}




\section{REFERENCES}

1. Alade I Classification of Nigerian Food: A Review. Food and Nutrition Bulletin. $\quad$ 1985; 7 (2): 59-63.

2. Musgrove P Feeding Latin America's Children. The World Bank Research Observer. 1993; 8 (1): 23-46.

3. World Bank Investing in Health. World Development Report 1993. New York: Oxford University Press. 1993.

4. World Bank Better Health in Africa: Experience and Lesson Learned. World Bank Development in Practice. Washington. DC: The World Bank. 1994.

5. Claeson M, Griffin C, Johnson T, Mclachlan M, Soucat A, Wagstaff A and A Yazbeck Health, Nutrition and Population; World Bank Poverty Reduction Strategy Source Book. Washington D.C. The World Bank. 2001.

6. Flores $\mathbf{R}$ Health and Nutrition: Emerging and Reemerging Issues in Developing Countries. In Pinstrup-Andersen, and Pandya-Loveh,R. (eds) The Unfinished Agenda: Perspectives on Overcoming Hunger Poverty and Environmental Degradation. Washington D.C.: International Food Policy Research Institute. 2001.

7. Smith LC and L Haddad Overcoming Child Malnutrition in Developing Countries: Past Achievements and Future Choices. In Pinstrup-Andersen, and Pandya-Loveh, R. (Eds.) The Unfinished Agenda: Perspectives on Overcoming Hunger Poverty and Environmental Degradation. Washington D.C.: International Food Policy Research Institute. 2001.

8. World Bank Agriculture for Development. World Development Report 2008. New York: Oxford University Press. 2008.

9. Diao X, Hazell P, Resnick $\mathbf{D}$ and J Thurlow The Role of Agriculture in Development: Implications for Sub-Saharan Africa. International Food Policy Research Institute Research Paper (153). Washington D.C: International Food Policy Research Institute. 2007.

10. Benson T Improving Nutrition as a Development Priority: Addressing Undernutrition in National Policy Processes in Sub-Saharan Africa. IFPRI Research Paper 156. Washington D.C: International Food Policy Research Institute. 2008.

11. Martorell R Obesity: A Emerging Health and Nutrition Issues in Developing Countries.In Pinstrup-Andersen, and Pandya-Loveh,R. (Eds) The Unfinished 
Agenda: Perspectives on Overcoming Hunger Poverty and Environmental Degradation. Washington D.C.: International Food Policy Research Institute. 2001.

12. Hedley AA, Ogden CL, Johnson CL, Carroll MD, Curtin LR and MK Flegal Prevalence of Overweight and Obesity among US Children, Adolescents and Adults, 1999 - 2002. Journal of American Medical Association. 2004; 129 (23): 2847 - 2850.

13. Behrman JR The Impact of Health and Nutrition on Education. The World Bank Research Observer. 1996; 11 (1): 23-38.

14. Bello RA and GT Ijaiya Socio-economic Causes of Malnutrition and its Impact in Learning Capability and Productivity of School-age Children. International Journal of Educational Management. 1998; 2 (2): 120-126.

15. Glewwe $\mathbf{P}$ and EM King The Impact of Early Childhood Nutritional Status on Cognitive Development: Does the Time of Malnutrition Matter? The World Bank Economic Review. 2001; 15 (1): 81-114.

16. Gersovitz $\mathbf{M}$ and JS Hammer Infection Diseases, Public Policy and the Marriage of Economic and Epidemiology. The World Bank Research Observer. 2003; 18 (2): 129-158.

17. Pacey A and P Payne. (eds.) Agricultural Development and Nutrition. London: Hutchinson Group. 1985.

18. Schiff $\mathbf{M}$ and A Valdes The Link Between Poverty and Malnutrition: A Household Theoretic Approach. World Bank Policy Research Working Paper (536). 1990.

19. Shi A How Access to Urban Potable Water and Sewerage Connections Affect Child Mortality. World Bank Policy Research Working Paper(2274). 2000.

20. Newborn-Cook CV, White D, Svenson LW, Demianczuk NN, Bott $N$ and J Edwards Where and to What Extent is Prevention of Low Birth Weight Possible. Western Journal of Nursing Research. 2002; 24. (8): 887 - 904.

21. Hedley AA, Ogden CL, Johnson CL, Carroll MD, Curtin LR and MK Flegal Prevalence of Overweight and Obesity among US Children, Adlenscents and Adults, 1999 - 2002. Journal of American Medical Association. 2004; $129 \quad$ (23): $2847-2850$.

22. Food and Agriculture Organization (FAO) The State of Food Insecurity in the World. Rome: FAO. 2005.

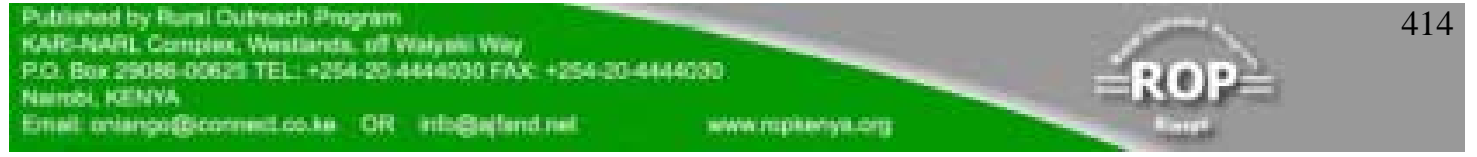


23. Von Braun J Focus on the World's Poorest and Hungry People. In IFPRI (ed) Eliminating Hunger and Reducing Poverty: The Perspectives. Washington D.C : International Food Policy Research Institute. 2006.

24. Food and Agriculture Organization (FAO) Food Deprivation Trends: Midterm Reviews of Progress towards the World Food Summit Target. FAO Statistical Division. Working Paper (7) 2006.

25. Smith LC and D Wiesmann Is Food Insecurity more severe in South Asia of Sub-Saharan Africa? International Food Policy Research Institute Discussion Paper (712). Washington D.C: International Food Policy Research Institute. 2007.

26. Ueyama M Mortality, Mobility and Schooling Outcomes among Orphans: Evidence from Malawi. International Food Policy Research Institute Discussion Paper( 710). Washington D.C: International Food Policy Research Institute. 2007

27. World Book Nutrition. Chicago: World Book Inc. 2001.

28. Africa Development Bank (ADB) Gender, Poverty and Environmental Indicators on Africa Countries. Abidjan ADB. 2003.

29. Population Reference Bureau (PRB) World Population Data Sheet. Washington D.C: Population Reference Bureau. 2008.

30. Oyeniyi TA Fundamental Principles of Econometrics. Lagos: Cadre Publication Ltd. 1997.

31. Greene WH Econometric Analysis. Delhi: Dorling Kindersley. 2003.

32. Fritschel H Fighting Hidden Hunger. In Pinstrup-Andersen, and PandyaLoveh, R. (Eds) The Unfinished Agenda: Perspectives on Overcoming Hunger Poverty and Environmental Degradation. Washington D.C.: International Food Policy Research Institute. 2001.

33. World Bank Attaching Poverty World Development Report 2000/2001. New York: Oxford University Press. 2001.

34. Gillespie S and S Kadiyale HIV/AIDS and Food and Nutrition Security: From Evidence to Action: International Food Policy Research Institute .Food Policy Review (7). Washington D.C: International Food Policy Research Institute. 2006. 
35. Thurlow J Is HIV/AIDS Undermining Botswana's Success Story? Implications for Development Strategy. Washington D.C: International Food Policy Research Institute. 2007.

36. Gillespie S AIDS, Poverty and Hunger: An Overview. In Gillespie S (ed.) AIDS, Poverty and Hunger: Challenges and Responses. Washington D.C: International Food Policy Research Institute. 2006.

37. Stillwaggon, E The Ecology of Poverty, Nutrition, Parasites and Vulnerability of HIV/AIDS. In Gillespie $S$ (ed.) AIDS, Poverty and Hunger: Challenges and Responses. Washington D.C: International Food Policy Research Institute. 2006.

38. Barnet T HIV/AIDS, Nutrition and Food Security: Looking to Future Challenges. In Gillespie S (ed.) AIDS, Poverty and Hunger: Challenges and Responses. Washington D.C: International Food Policy Research Institute. 2006. 